\title{
Metformin Reduces Insulin Requirement in Type 1 (Insulin-Dependent) Diabetes
}

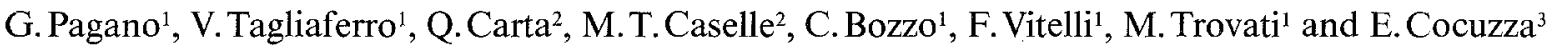 \\ ${ }^{1}$ Department of Internal Medicine, University of Turin, ${ }^{2}$ USL 1-23, Presidio Ospedaliero, Turin and ${ }^{3}$ Spemsa s.p. A., Florence, Italy
}

\begin{abstract}
Summary. The effect of metformin on Type 1 (insulin-dependent) diabetes has been assessed with the artificial pancreas. Fourteen Type 1 diabetic patients of normal body weight received in addition to their usual insulin therapy $850 \mathrm{mg}$ metformin or placebo three times a day for 4-6 weeks. The sequence was placebo-metformin in eight patients and metformin-placebo in the other six. On the last day of metformin or placebo treatment, an artificial pancreas was used for about $36 \mathrm{~h}$ to assess insulin requirement. There was a $25.8 \%$ reduction in insulin requirement during metformin management despite slightly lower blood glucose levels $(5.25 \pm 0.20$ versus $5.98 \pm 0.18 \mathrm{mmol} / \mathrm{l}, p<0.01$ ). Maximum reduction (about $50 \%$ ) occurred $2 \mathrm{~h}$ after both lunch and dinner. There was no nocturnal effect. A marked decrease in specific insulin binding before metformin was found $\left(0.56 \pm 0.27 \%\right.$ to $10^{7}$ monocytes versus $2.82 \pm 0.75$ of control subjects) and significant in-
\end{abstract}

crease after metformin $(1.36 \pm 0.36 \%, p<0.05)$. There were no significant changes in blood lactate, total and HDL-cholesterol, triglycerides and C-peptide levels.

These results show that insulin receptor binding is diminished in Type 1 diabetes, perhaps as a consequence of higher peripheral blood insulin levels and that metformin can improve binding, and so reduce the amount of insulin needed to reach euglycaemia. The insulin sparing effect is greatest after meals, and interference with intestinal absorption of sugars may also be important. It follows that metformin could be usefully administered to Type 1 diabetic patients with unimpaired liver and renal function to reduce their insulin requirement.

Key words: Type 1 diabetes, biguanides, metformin, insulin receptors, insulin therapy, artificial pancreas, Biostator.
Biguanides lower blood glucose concentration, although in practical terms their effect is only evident in diabetes mellitus [1]. The underlying mechanism is not fully understood, but support for a peripheral action has been shown recently by an enhancement of insulin receptors in the presence of phenformin [2] and metfor$\min [3]$. Studies in vitro $[2,3]$ have shown a rapid dosedependent effect of biguanides on insulin binding to target cells, unrelated to changes in blood glucose or insulin concentration as in the case of other drugs [3]. This direct effect offers a more logical basis for earlier work showing sufficient potentiation of the peripheral [4] and hepatic effect to justify the use of biguanides in the treatment of Type 1 (insulin-dependent) diabetes mellitus. The combination of a biguanide with conventional insulin treatment in Type 1 diabetes, therefore, is an attractive possibility for many reasons, including the induced malabsorption of glucose [5] and other hexoses [6] and the possible control of secondary insulin-resistance.
The effectiveness of combined biguanide-insulin therapy in experimental animals [6] and in man [7] has hitherto been based on qualitative rather than quantitative evidence. The aim of the present work was to test the hypothesis that combined biguanide-insulin therapy may be usefully employed in Type 1 diabetic patients. The artificial endocrine pancreas was used to evaluate the insulin requirement over $24 \mathrm{~h}$ sedentary life in the presence or absence of metformin. The positive results of the acute administration of metformin in Type 1 diabetes have been reported recently [8].

\section{Subjects and Methods}

\section{Subjects}

All Type 1 diabetic patients under 60 years of age, with normal liver and kidney function, attending our outpatients clinic, were invited to take part in this 6-month study. Fifteen gave informed consent, of whom one dropped out after the first artificial pancreas session. Four- 
Table 1. Data for the 14 patients at the end of the control period without metformin

\begin{tabular}{|c|c|c|c|c|c|c|}
\hline Patients & $\begin{array}{l}\text { Age } \\
\text { (years) }\end{array}$ & Sex & $\begin{array}{l}\text { Duration of } \\
\text { diabetes } \\
\text { (years) }\end{array}$ & $\begin{array}{l}\text { Ideal body } \\
\text { weight } \\
(\%)\end{array}$ & $\begin{array}{l}\text { Insulin dose } \\
\text { during the } \\
\text { last } 2 \text { months } \\
\text { (U/day) }\end{array}$ & $\begin{array}{l}\mathrm{HbA}_{1(a+b+c)} \\
(\%)\end{array}$ \\
\hline \multicolumn{7}{|c|}{ Placebo-metformin } \\
\hline 1 & 52 & M & 22 & +10 & 75 & 10.8 \\
\hline 2 & 57 & M & 5 & +7 & 58 & 10.4 \\
\hline 3 & 60 & M & 20 & +7 & 36 & 8.7 \\
\hline 4 & 36 & M & 3 & -5 & 75 & 7.4 \\
\hline 5 & 31 & M & 4 & +4 & 44 & 9.2 \\
\hline 6 & 45 & $\mathrm{~F}$ & 2 & +3 & 56 & 10.7 \\
\hline 7 & 47 & M & 5 & +12 & 35 & 10.1 \\
\hline 8 & 31 & $\mathbf{F}$ & 6 & -13 & 45 & 9.9 \\
\hline \multicolumn{7}{|c|}{ Metformin-placebo } \\
\hline 9 & 35 & M & 5 & -9 & 62 & 9.6 \\
\hline 10 & 48 & M & 3 & +12 & 42 & 10.8 \\
\hline 11 & 43 & M & 8 & +7 & 70 & 9.8 \\
\hline 12 & 48 & M & 5 & +4 & 44 & 10.0 \\
\hline 13 & 27 & M & 16 & -3 & 50 & 8.9 \\
\hline 14 & 48 & $\mathrm{M}$ & 2 & +6 & 35 & 7.5 \\
\hline Mean \pm SEM & $43.4 \pm 2.7$ & & $7.6 \pm 1.8$ & & $51.9 \pm 3.9$ & $9.6 \pm 0.3$ \\
\hline
\end{tabular}

teen adult Type 1 diabetic patients were studied ( 12 male, 2 female; mean age $43 \pm 3$ years [SEM]; within $+12 \%$ and $-13 \%$ ideal body weight). They had been receiving insulin for $2-22$ years, and, at the beginning of the experiment, were in fair metabolic control (glycosylated stable haemoglobin $\mathrm{A}_{1 \mathrm{a}+\mathrm{b}+\mathrm{c}} 9.56 \pm 0.30 \%$ ). Their liver and kidney function was normal (liver enzymes and protein electrophoresis in the normal range, blood creatinine $<110 \mu \mathrm{mol} / 1$, normal urinalysis). They showed no residual B cell function, as assessed by plasma C-peptide determination $(0.64 \pm 0.06 \mathrm{mmol} / 120 \mathrm{~min}$ after $1 \mathrm{mg} \mathrm{IV}$ glucagon). Diet, physical activity and insulin dose (51.9 $\pm 3.86 \mathrm{U} /$ day) remained unchanged throughout the study (Table 1).

\section{Methods}

Metformin $850 \mathrm{mg}$ (Glucophage, Spemsa Florence, Italy) or a placebo was given three times a day before the main meals for 4-6 weeks. Placebo was given before metformin in eight patients, and metformin after placebo in the other six. At the end of placebo or metformin treatment, patients were subjected to artificial pancreas control (Biostator, Miles Laboratories, Elkart Indiana, USA) to determine insulin requirement during a 3-day hospitalisation, during which automatic IV management ran from $19.00 \mathrm{~h}$ on day 1 to $07.00 \mathrm{~h}$ on day 3 . The static plus dynamic control mode $(3: 1)$ was used for insulin administration. The preselected constants were: KF (a constant for falling glucose levels) $=166$; BI (the preselected 'basal' level of glucose at which the basal insulin infusion rate is administered $=4.4 \mathrm{mmol} / \mathrm{l}$; QI (the inverse for the static gain for insulin infusion) $=30$; RI (the basal insulin infusion rate at the preselected 'basal' glucose level) $=$ $0.05 \mathrm{mU} \cdot \mathrm{kg}^{-1} \cdot \mathrm{min}^{-1}$. No account was taken of the insulin requirement for the first $12 \mathrm{~h}(19.00-07.00 \mathrm{~h})$, which was used as equilibration period. Meals were given at $07.00 \mathrm{~h}(300 \mathrm{kcal}), 11.30 \mathrm{~h}(700 \mathrm{kcal})$ and $17.30(700 \mathrm{kcal})$. The composition of meals in both metformin and placebo treatments was the same: $50 \%$ carbohydrates, $30 \%$ fats and $20 \%$ proteins.

At $06.30 \mathrm{~h}$ on day 2 of Biostator application, venous blood was withdrawn from an antecubital vein during Biostator-inducet euglycaemia after an overinght fast for the following determinations: lactate [9], total and HDL cholesterol [10], triglycerides [11]. The sensitivity and coefficients of variation for each assay in our laboratory are as follows: glycaemia $0.10 \mathrm{mmol} / 1,2.5 \%$; lactate $0.10 \mathrm{mmol} / 1,4.8 \%$; cholesterol $0.15 \mathrm{mmol} / 1,5.1 \%$; triglycerides $0.12 \mathrm{mmol} / 1,6.2 \%$; Cpeptide $0.03 \mathrm{mmol} / 1,6.6 \% ; \mathrm{HbA}_{1 \mathrm{a}+\mathrm{b}+\mathrm{c}} 0.1 \%, 3.4 \%$. At the same time,
$20 \mathrm{ml}$ blood was collected from the antecubital vein to provide monocytes for insulin binding. Cells were isolated by gradient centrifugation according to Böyum [13] and suspended in Hepes buffer $(100 \mathrm{mmol} / 1, \mathrm{pH} 8)$ at a concentration of $10^{7} / \mathrm{ml}$ monocytes, in the presence of $1 \mathrm{ng}{ }^{125} \mathrm{I}$-monoiodoinsulin $(50-80 \mu \mathrm{C} / \mu \mathrm{g})$ prepared in our laboratory [14] and $100 \mu \mathrm{g} / \mathrm{ml}$ native insulin to determine the specific hormonal binding. Incubation was performed for $100 \mathrm{~min}$ at $15^{\circ} \mathrm{C}$, and cells were separated according to Beck-Nielsen et al. [15]. Results are expressed as a percentage of specific binding of the total amount of insulin present in the medium. This measurement was carried out in five diabetic patients and in six well-matched healthy subjects.

\section{Results}

Metformin treatment was well tolerated by all patients, although most had transient abdominal pain and nausea for the first week of therapy.

Table 2 shows the amount of insulin administered by the Biostator for $24 \mathrm{~h}$ during placebo-metformin sequence (patients 1-8) and metformin-placebo sequence (patients 9-14). It can be seen that a requirement of $70.9 \pm 8.4 \mathrm{U} /$ day in the absence of metformin is replaced by a value of $51.7 \pm 6.18 \mathrm{U} /$ day. This corresponds to a reduction of $25.8 \%(p<0.001)$. Mean plasma glucose values were slightly lower after metformin therapy $(5.9 \pm 0.18 \mathrm{mmol} / 1$ after placebo and $5.3 \pm$ $0.17 \mathrm{mmol} / 1$ after metformin). Comparison between the two sequences made it clear that metformin did not have a sequence-effect. In subsequent calculations, therefore, the results were no longer referred to their sequence.

The hourly insulin requirement is illustrated in Figure 1. Mean 30 min plasma glucose values during Biostator application are shown: less insulin was administered by the Biostator during treatment with metformin. 
Table 2. Daily insulin requirement determined by the artifical pancreas on the last day of treatment with placebo or metformin following overnight stabilization. The placebo-metformin sequence was followed in cases 1-8, the metformin-placebo sequence in cases 9-14

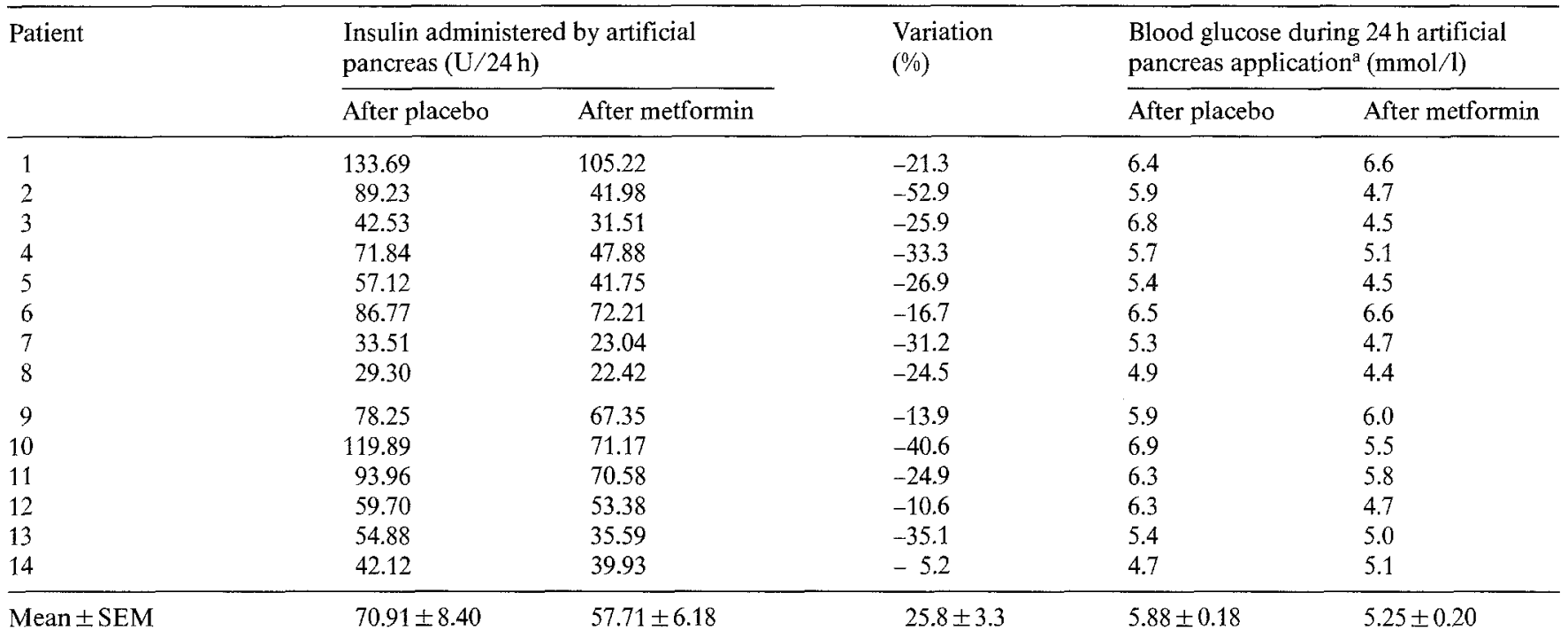

a Blood glucose values are the mean of 1,440 determinations per patient

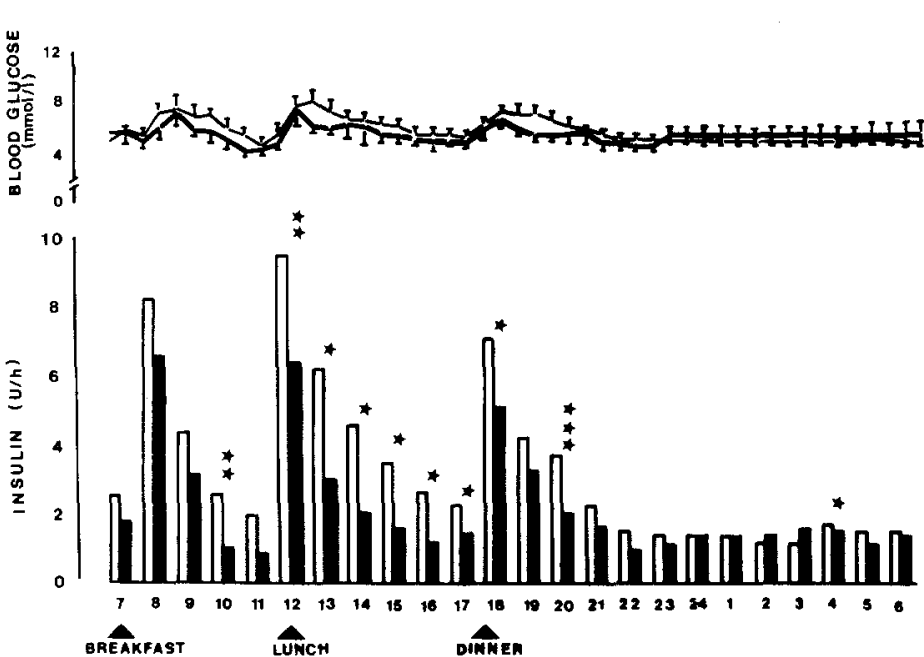

Fig. 1. Mean blood glucose levels are plotted every 30 min during control with (thick line) and without (thin line) metformin. Insulin administered is plotted hourly for day 2 on the artificial pancreas. $\square$ without metformin. $\square$ with metformin.

${ }^{*} p<0.05 \quad * * p<0.01 \quad * * * p<0.005$

In addition, the most significant differences were noted after meals: $50 \%$ reduction $2 \mathrm{~h}$ after lunch and dinner, respectively.

Chances in other plasma values are not significant: lactate concentrations varied from $1.1 \pm 0.08$ to $1.1 \pm$ $0.07 \mathrm{mmol} / 1$; total cholesterol concentrations from $4.7 \pm 0.25$ to $4.7 \pm 0.26 \mathrm{mmol} / \mathrm{l}$; HDL cholesterol from $1.15 \pm 0.07$ to $1.26 \pm 0.6 \mathrm{mmol} / 1$; triglycerides from $1.14 \pm 0.10$ to $1.18 \pm 0.15 \mathrm{mmol} / 1$.

Symptomatic hypoglycaemia needed a stable reduction in insulin administration as the study perceived in patients 2, 4 and 10 .

Means and individual insulin binding values in five diabetic patients and the six control subjects are given

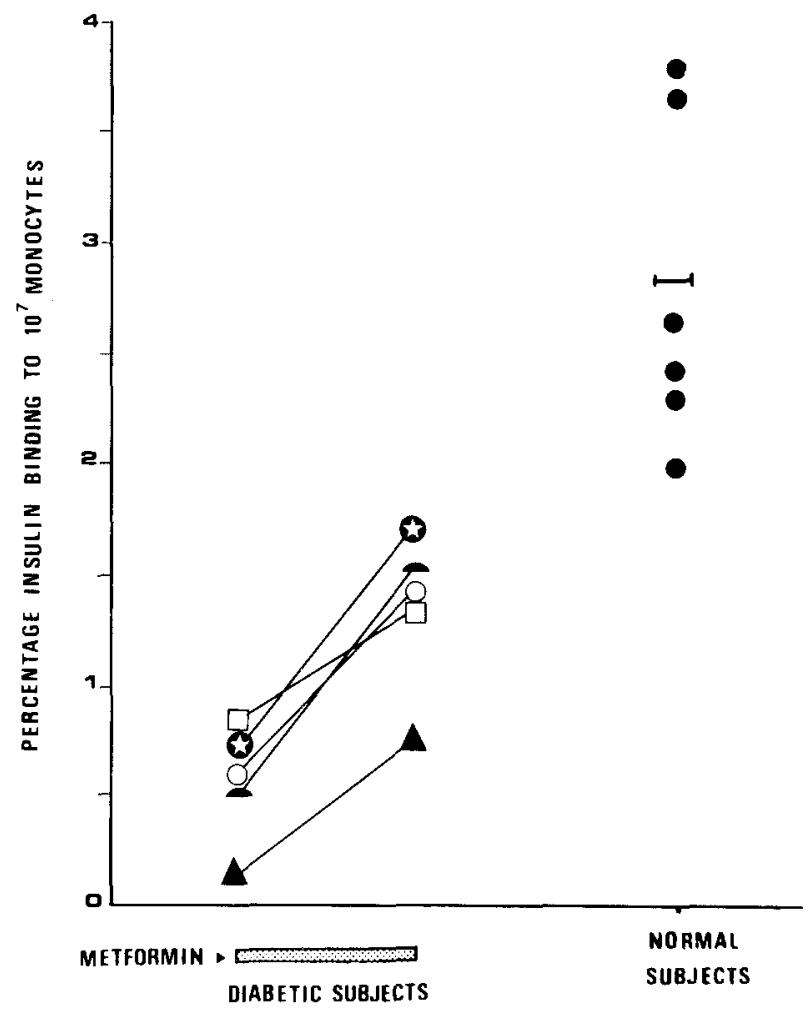

Fig. 2. Specific binding of ${ }^{125} \mathrm{I}$-monoiodoinsulin to $10^{7}$ monocytes from $20 \mathrm{ml}$ blood from five Type 1 diabetic patients and six well matched control subjects. The aspecific binding was subtracted by repeating the incubation in the presence or absence of $100 \mu \mathrm{g} / \mathrm{ml}$ cold insulin according to Beck-Nielsen et al. [15]. The second value was taken 4-6 weeks after the addition of metformin to the insulin treatment. Bar represents the mean value.

in Figure 2. The binding was well down in Type 1 diabetes, but rose to near the lower end of normal range after metformin. This increase was significant $(p<0.05)$, though the difference between it and normal levels was even more so $(p<0.001)$. 


\section{Discussion}

Peripheral hyperinsulinism may lead to down-regulation of insulin receptors [16] and thus make Type 1 diabetic patients less sensitive to the action of the exogenous hormone. Metformin improves insulin binding to target cells in vitro $[2,3]$ and might be expected to improve insulin sensitivity in Type 1 diabetic patients. Insulin binding to monocytes in our series was significantly lower than in normal subjects, and metformin treatment increased the number of insulin receptors on monocytes. These results agree with reports in vitro [2, $3]$ and in vivo [17] and give a rationale for the use of metformin in association with insulin treatment. Our results show that this approach is of practical value since there was a $25.8 \%$ decrease in daily insulin requirement after metformin. This reduction in insulin requirement is probably under-estimated owing to the slightly lower blood glucose values during metformin treatment. In five subjects there was a $39 \%$ increase in insulin binding to isolated monocytes after 4-6 weeks of metformin treatment, in agreement with results in vitro $[2,3]$. This may well be a fundamantel mechanism of the action of biguanides in diabetes.

A supplementary mechanism is suggested by the observation that a maximum reduction in insulin requirement took place after the two main meals. This is in line with the view that metformin alters the intestinal absorption of carbohydrates. It would also explain the absence of a nocturnal effect, though it should not be forgotten that the drug has a half-life of $3-5 \mathrm{~h}$ [18].

None of our patients displayed significant evidence of hyperlactataemia, indicating that this occurs mostly in patients with liver and renal failure [19] and is very rare when metformin is used [19]. By contrast with noninsulin-dependent diabetes [20], there was no significant change in blood cholesterol and triglycerides.

Our overall conclusion is that metformin can be administered to Type 1 diabetic patients with unimpaired liver and renal function without risk of hyperlactataemia. Its benefits include improved glycaemic control and a significant reduction in insulin requirement. Effects of this kind have been predicted in the past [7]. Their existence can now be demonstrated and gives support to the view that metformin acts directly on insulin receptors.

Acknowledgements. This study was partially supported by a grant of CNR $n^{\circ} 80.00528 .04$ and was presented at the Annual Meeting of the EASD, Amsterdam (16-19 September 1981).

\section{References}

1. Nattrass M, Alberti KGGM (1978) Biguanides. Diabetologia 14: $71-74$

2. Cohen D, Pezzino V, Vigneri $R$, Avola R, D'Agata R, Polosa $P$ (1980) Phenformin increases insulin binding to human culture breast cancer cells. Diabetes 29:329-331
3. Vigneri R, Pezzino V, Wong KJ, Goldfine ID (1982) Comparison of the in vitro effect of biguanides and sulfonylureas on insulin binding to its receptors in target cells. J Clin Endocrinol Metab 54: $95-100$

4. Kreisberg RA, Birmingham MD (1968) Glucose metabolism in normal and obese subjects. Effect of phenformin. Diabetes 17: $481-488$

5. Czyzyk A, Tawecky J, Sadowsky J, Ponikowska I, Szczepanik Z (1968) Effect of biguanides on intestinal absorption of glucose. Diabetes 17: 492-498

6. Creutzfeldt W, Willms B, Caspary W (1971) The mechanism of action of the blood glucose lowering biguanides. In: Rodriguez RR, Vallance-Owen J (eds) Diabetes. Proceedings of the VII Congress of the International Diabetes Federation, Buenos Aires 1970. Excerpta Medica, Amsterdam, pp 708-719

7. Bloom A, Kolbe RJ (1970) Phenformin in insulin-dependent diabetes. Br Med J 1: 660-662

8. Gin H, Slama G, Weissbrodt P, Poyanard T, Vexiau P, Klein JC, Tchobrousky G (1982) Metformin reduces post-prandial insulin needs in Type 1 (insulin-dependent) diabetic patients: assessment by artificial pancreas. Diabetologia $23: 34-36$

9. Noll F (1970) L-Lactat: Bestimmung mit LDH, GPT und NAD. In: Bergmayer HU (ed) Methoden der enzymatischen Analyse (2nd edn). Verlag Chemie Weinheim, New York, London pp $1433-1437$

10. Warnick RG, Albers JJ (1978) A comprehensive evaluation of the heparin-manganese precipitation for estimating high density lipoprotein-cholesterol. J Lipid Res 19: 65-76

11. Eggstein M, Kuhlman E (1970) Triglyceride und Glycerine. In: Bergmayer HU (ed) Methoden der enzymatischen Analyse (2nd edn). Verlag Chemie Weinheim, New York, London pp1765-1771

12. Melani F, Rubenstein AH, Oyer PE, Steiner DF (1970) Identification of proinsulin and C-peptide in human serum by specific immunoassay. Proc Nat Acad Sci 67: 148-166

13. Böyum A (1974) Separation of blood leucocytes, granulocytes and lymphocytes. Tissue Antigens 4: 269-274

14. Pagano G, Cassader M, Massobrio M, Bozzo C, Trossarelli GF, Menato $G$, Lenti $G(1980)$ Insulin binding to human adipocytes during late pregnancy in healthy, obese and diabetic state. Horm Metab Res 12: 177-181

15. Beck-Nielsen H, Pedersen O, Lindskov HO (1979) Increased insulin sensitivity and cellular insulin binding in obese diabetics following treatment with glibenclamide. Acta Endocrinologica 90: $451-462$

16. Bar RS, Gorden P, Roth J, Kahn CR, De Meyts P (1976) Fluctuation in the affinity and concentration of insulin receptors on circulating monocytes of obese patients. Effect of starvation, refeeding and dieting. J Clin Invest 58: 1123-1135

17. Holle A, Mangels W, Dreyer M, Kuhnau J, Rudiger HW (1981) Biguanide treatment increases the number of insulin-receptor sites on human erythrocytes. New Engl J Med 305: 563-566

18. Mehnert $H$ (1969) Pharmacokinetics of blood glucose lowering biguanides derivatives. Act Diabet Lat 6 (Suppl 1): 137-142

19. Luft D, Schmulling RM, Eggstein M (1978) Lactic acidosis in biguanide-treated diabetics. Diabetologia 14:75-87

20. Owen WC, Kreisberg RA, Siegal AM (1971) Carbohydrate-induced hypertriglyceridemia: inhibition by phenformin. Diabetes 20: 739-744

Received: 19 July 1982

and in revised form: 14 February 1983

Professor G. Pagano

Istituto di Medicina Interna

Cattedra di Patologia Medica C

Corso Polonia 14

I-10126 Torino

Italy 